\title{
線溶系と組織修復（骨・筋肉形成）
}

湯浅将人 ${ }^{1 *}$, Breanne H.Y. GIBSON ${ }^{2}$, Jonathan G. SCHOENECKER ${ }^{2}$

\section{Fibrinolytic system in tissue healing: Bone and Muscle}

\author{
Masato YuAsA, Breanne H.Y. Gibson, Jonathan G. Schoenecker
}

要約 : 骨格系の組織のうち, 骨・筋肉組織は, 人体の支持組織として不可欠な組織である.この筋骨格系の維 持機能は非常に重要である. 組織が損傷する, すなわち骨折, 筋肉打撲といった筋骨格系の組織損傷は日常し ばしば発生し，その組織損傷は直ちに正しく修復されなければならない.この修復機構は厳密に体内で制御さ れている. 組織損傷の下では, 凝固線溶系の活性化が不可欠である. 組織内血管が, 筋骨格系組織の損傷によっ て, 破綻が拈き, 瞬く間に凝固線溶系カスケードが作用し修復機能が働く.フィブリンが形成され止血に働き, 役割を終えたフィブリン網はプラスミンによって分解される.このプラスミンを中心とした線溶系は, 実はフィ ブリンの溶解といった古典的作用だけでなく, 多様な生理的および病態生理的作用を果たしている. 本稿では, この凝固線溶機能と骨と筋肉組織修復の関与とその機序に関して, 今までの知見とともに概説したい.

Key words: fibrinolytic system, bone healing, muscle healing, musculoskeletal disease, heterotopic ossification

\section{1.はじめに}

人体の組織のうち, 骨, 筋肉といった筋骨格系は, 内臓藏器を守り, また日常動作を可能にしている必 須な臓器である。骨はカルシウムの貯蔵組織として 胎生期から種々のサイトカインやホルモンにより時 間的・空間的に厳密に制御され一生涯にわたり恒常 性が保たれる，筋は体の $40 \%$ を占めるといわれ，伸 張と収縮により関節の可動を可能にしている。この 筋骨格系は日々の動作により，ときとして組織損傷 を受ける，幸いなことに，通常我々の体は，この損 傷に素早く反応し, 修復するといった治癒反応が起 きている，組織治癒としては, 出血, 止血, 急性炎 症, 組織増殖, リモデリングを経る。しかしながら, 炎症疾患である糖尿病や肥満, 自己免疫疾患といっ た疾患を有する場合, この修復機構が損なわれ，骨

\footnotetext{
1 東京医科歯科大学整形外科

2 ヴァンダービルト大学

*責任者連絡先 :

東京医科歯科大学整形外科

干 113-8519 東京都文京区湯島 1-5-45

Tel: 03-5803-5279, Fax: 03-5803-5281

E-mail: yuasa.orth@tmd.ac.jp
}

修復不全である偽関節や骨量減少であるオステオペ ニア, 病的な筋量減少であるサルコペニアといった 状態に陥る ${ }^{1)}$.ささらに組織損傷の修復の失敗は重大 な障害を招く，骨癒合不全や筋肉治癒障害によって 四肢機能低下や, 慢性的な疼痛, 可動域の低下, 四 肢の機能障害等をもたらし, ADL を著しく損なう結 果を招く2,3).

凝固線溶機能は人体維持にとって不可欠な機能で あり，筋骨格においても非常に重要な役割を果たし ている. 骨折など外傷や, 術中術後に伴う凝固能力 の低下は過剩出血を引き起こすことがあり，ときに 致死的となる。一方, 人工関節術後や春椎手術後の 凝固過剩は血栓を引き起こすことがあり, 時として 重篤な症状を引き起こす，生体内において，この凝 固線溶機能のバランスが厳密に制御され, 筋骨格組 織が維持されている ${ }^{2,4)}$.

筋骨格系システムは豊富なエネルギー供給が必要 とされ，そのためにはエネルギー源を運搬する血行 が豊富でなければならず, 筋骨格系も血管が張り巡 らされている。 それゆえ, 筋骨格組織損傷による血 管の損傷は避けられない. 血管の損傷により, 出血, その後血腫すなわち血腫凝固となり, 組織修復と共 
にそれは消失する，凝固線溶系システムは，出血に 伴うフィブリンによる凝固と, 血腫を溶解するプラ スミンによる線溶と機能しているが, このシステム は, 組織損傷後の一次止血といった古典的役割に寄 与しているだけでなく, 組織修復の中で様々に寄与 していることが示されている ${ }^{5-10)}$. 線溶系タンパク であるプラスミンは, マトリックスプロテアーゼ （MMP）の活性化を介して細胞外基質を分解し，こ れによる細胞外基質に存在する血管内皮細胞増殖因 子 (vascular endothelial growth factor: VEGF) やトラ ンスフォーミング成長因子（transforming growth factor- $\beta$ : TGF- $\beta$ ） などの成長因子を遊離させる ${ }^{11-13)}$. また単核球やマクロファージの移動を促進したり ${ }^{14)}$, 細胞内シグナルに関しては, 細胞膜に発現するuPA 受容体やプロテアーゼ活性化受容体（proteaseactivated receptors: PARs）を介するシグナルの活性化 など多岐にわたる ${ }^{15)}$.このようにプラスミンは古典 的なフィブリンの溶解といった作用だけでなく，血 管新生, 走化性, 恒常性維持や細胞分化等組織修復 の際の様々な現象に寄与している。ここでは筋骨格 損傷と凝固線溶系の関係を我々の研究成果を中心に これまでの知見とともに説明する。

\section{2. 線溶系と筋骨格系損傷後の急性反応}

線溶系タンパクであるプラスミンは, 組織型プラ スミノゲンアクチベータ（tPA）及びウロキナーゼ型 プラスミノゲンアクチベータ（uPA）により前駆体 であるプラスミノゲンが分解され，酵素活性を有す るタンパクである.プラスミンの古典的作用以外の 多岐にわたる生体での機能ゆえに, 組織損傷後のプ ラスミン活性は非常に重要で, これは厳密に制御さ れなければならない.

ひとたび筋骨格系損傷が発生すると, 急性の反応 が起きる。すなわち, 出血の制御, 組織の低酸素化 の制御といった反応である. まず凝固系が活性化し, 止血に作用する。 この際, フィブリンが血管内, 血 管外に沈着する．血管内フィブリンは血栓となり血 液漏出を防ぐ. 一方血管外フィブリンは損傷組織内 で細胞外基質マトリックスとなり, 組織修復を保護 する。すなわちフィブリンマトリックスにおいて,
tPA やuPAによりプラスミノゲンからプラスミンに 分解され活性化し, フィブリンを分解し, 低酸素状 態を改善, 組織機能を回復させる.プラスミンは沈 着フィブリンを分解し,さらに炎症反応を促進させ, 損傷した壊死組織などの除去に作用する。それらが 完了したのち, プラスミンはVEGFの産生を促進さ せ，血管新生を導くことにより，局所の低酸素状態 を改善する ${ }^{12)}$. このように効果的な組織修復は, フィブリン形成から惹起されるプラスミン活性と いったイベントが厳格に制御されてはじめて完成す る. いいかえれば, このバランスが崩れると筋骨格 系損傷後, 組織修復の失敗が起き, そして組織変性 を招き病的状態となる。

\section{3. 骨修復と凝固線溶系}

\section{1）骨折修復の過程}

骨化パターンは 2 通り存在する。膜性骨化と内軟 骨性骨化である。膜性骨化は, 未分化な細胞から骨 芽細胞に分化し，それが骨に変換される骨化形態で ある。一方, 内軟骨骨化は軟骨細胞の形成と増殖 · 分化後, 骨芽細胞によって骨に置換される骨化形態 である．両者ともに生体の通常の骨成長と同じプロ セスである ${ }^{16,17)}$. 骨の修復, 中でも骨折の修復は組 織損傷を伴っているという点で骨の成長と異なって いる。 その修復過程において乗り越えなくてはなら ない様々な課題が存在する. すなわち, 出血, 低酸 素といった局所の環境の変化である，骨折によって， 血行に富んだ骨はまず血管の破綻が発生し, 出血が 起きる. 止血のためにフィブリンが産生される。骨 折の治癒の過程は古くから研究されているが 18-20), 時間的空間的な血管再生の治癒過程を詳細に示した ものは少ない. 我々はマウスの大腿骨骨折モデルを 用いることによって, 骨折前は骨内に存在した血行 が骨折により骨折部の血行が途絶し，無血管野が形 成されることを可視化した ${ }^{16)}$. その無血管野に軟骨 細胞が増殖・分化し, 軟骨仮骨を形成, その後膜性 骨化と内軟骨骨化のプロセスの中で血行が中心部に 進展し, 骨の連続性が完成すると同時に血行が回復 する. 骨血行の結合ののち, 骨のリモデリングと共 に血行もリモデリングしていく．このように血流が 


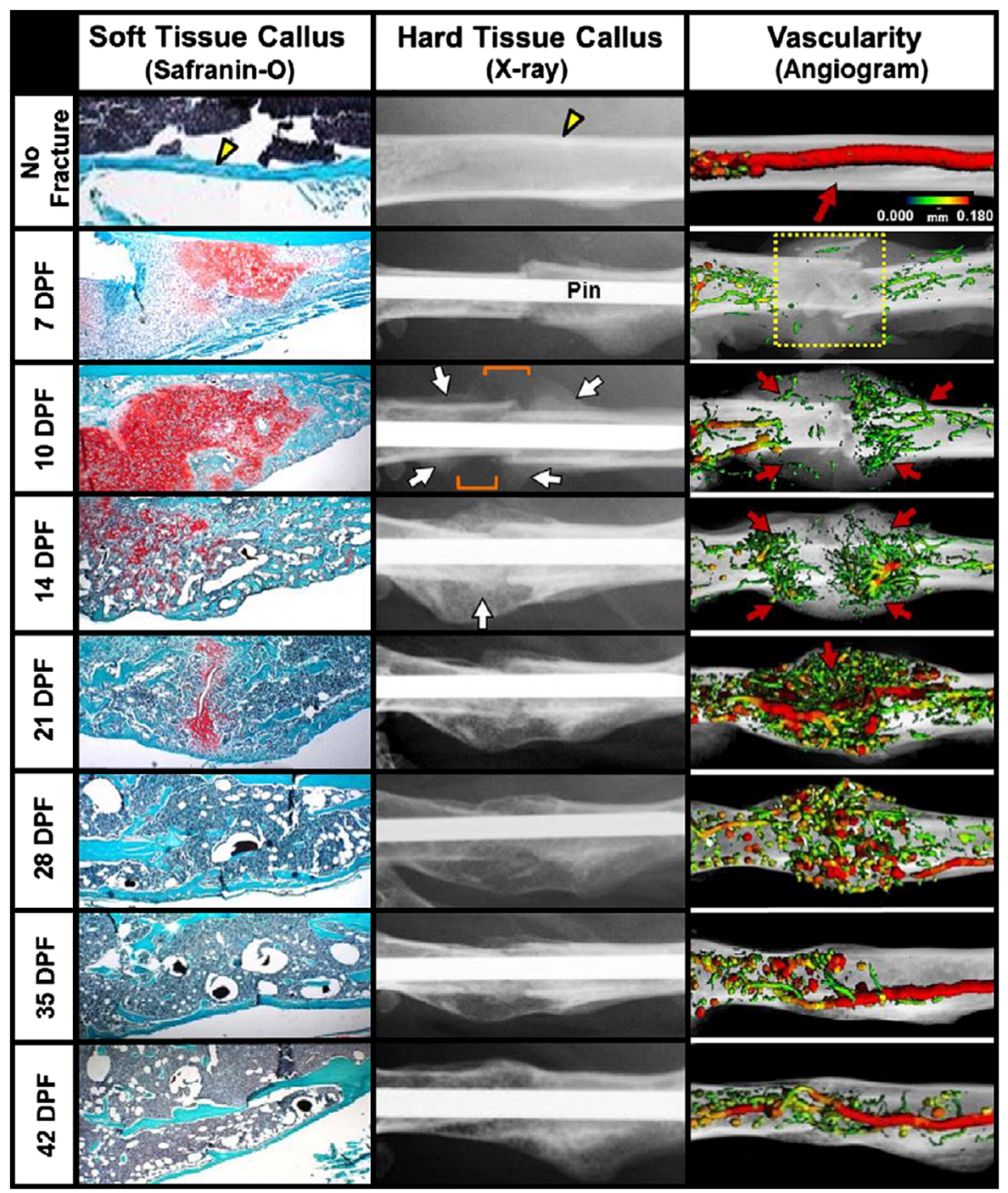

四 1 骨折前, 骨折後の時間空間的組織修復経過.レントゲン像とアンジオグラムで7DPF から 21DPFにかけて骨製の架橋 と共に血行がつながるのが示されている（DPF: Days post fracture）

骨修復に非常に重要であることが分かる（図 1).

2）骨折修復における線溶系の役割

骨折の修復過程の不可欠なプロセスはフィブリン マトリックスの形成といわれている ${ }^{21)}$ 。骨折が発生 すると，損傷部位でのトロンビンがフィブリンと血 小板凝集をもたらし出血を止める. そして好中球が 治癒促進のため局所の炎症を促進する。フフィブリン 沈着と好中球活性により， $\alpha \mathrm{M} \beta 2$ インテグリンを表 面上にもつマクロファージが活性化し, それがイン ターロイキン 1,6 や TNF $\alpha$ といったサイトカイン産生 を促す ${ }^{22-24)}$. フィブリンならびに遊走マクロファー ジの表面に結合したプラスミノゲンはプラスミンに
変換される.このプラスミンは組織に蓄積したフィ ブリンを除去することによって修復過程を促進する とともに抗炎症マクロファージを活性化する ${ }^{23-25)}$. マクロファージによって壊死組織とフイブリン分解 産物が除去され，さらに間葉系細胞が浸潤する。さ らにプラスミンは骨折部の Pro-MMP9 や VEGF と いった成長因子を活性化し, 組織のリモデリングと 血管新生を促進する ${ }^{12,26)}$ 。すなわち, 損傷組織と フィブリンの除去により，一度破断した血管新生が 起こり，骨形成が進んでいく，このように線溶系夕 ンパクであるプラスミンはフィブリン依存的メカニ ズムと非依存的なメカニズムによってこの修復過程 


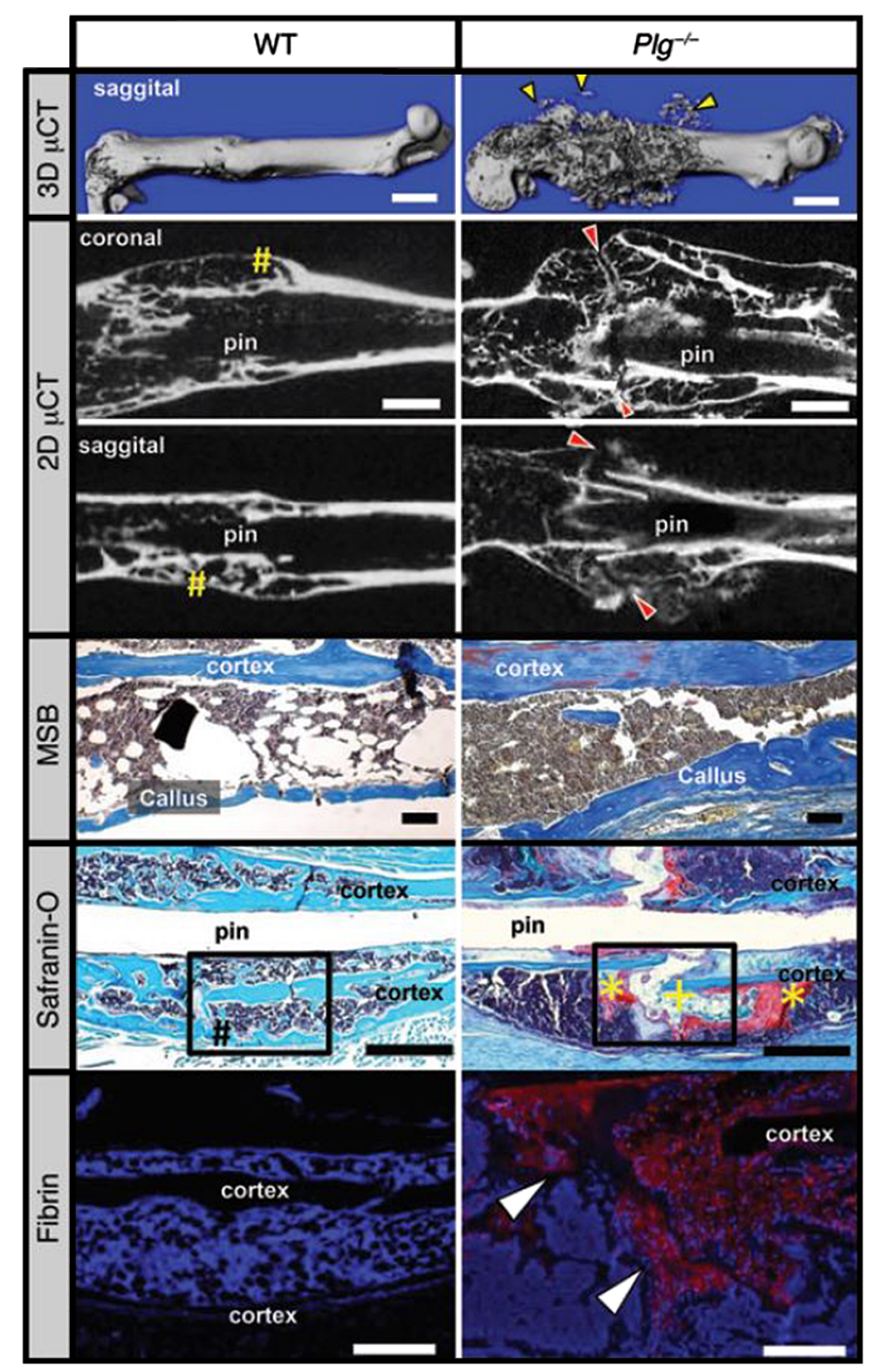

困 2 野生型マウスとプラスミノゲン欠損マウスの骨折後 42 日でのCT と組織像. プラスミノゲン欠損マウスにおいてフィ ブリンの残存と，骨折架橋が不十分であることが示されている.

に携わっていることが分かる.

そこで凝固線溶系遺伝子修飾マウスを用いて，骨 折修復での凝固と線溶の関与を検証した ${ }^{10)}$ 。骨折修 復初期の不可欠なマトリックスであるといわれる フィブリンの役割を調べるために, フィブリノゲン 欠損マウスの骨折修復を検証したところ，骨折後出 血はやや多い傾向が見られたが，骨折修復は驚くべ きことに正常であった。一方, プラスミノゲン欠損 マウスは，骨折修復が損なわれ，偽関節を呈してい た（図 2)。病理組織学的には軟骨形成は両者とも認 められるものの, プラスミノゲン欠損マウスにおい て血管の形成がそしくさらに産生されたフィブリン
が除去されずに遺残し，軟骨部と骨形成部との境界 にバリアのように存在していた。このプラスミノゲ ン欠損マウスに対し, 薬理学的にフィブリノゲン産 生を抑制すると, 部分的ではあるが骨折修復が改善 した。 これらの結果から, 骨折修復においてフィブ リン分解というフィブリン依存的なプラスミンの作 用の他, フィブリン非依存的なプラスミンの作用が 存在することが示唆された.

一方，大腿骨骨孔修復モデルにおけるプラスミノ ゲン欠損マウスに执いては, 軟骨形成と骨形成, 骨 芽細胞増殖が減少していた ${ }^{27)}$. VEGF と TGF $\beta$ の発 現量が低く, 血管形成も減少していた。骨修復モデ 
ル間で一部相違はあるものの, プラスミノゲンが大 いに骨修復に影響があることが示唆された。

線溶系の調節因子である tPA, uPA や PAI-1 の骨折 修復寄与の知見も散見される. uPA 欠損マウスの骨 折は, 破骨細胞の移動と血管架橋がそしく結果とし て仮骨のリモデリングがそしかった ${ }^{28)}$. 一方 tPA欠 損マウスにおいて, 大腿骨骨欠損モデルにおいて, 骨修復が遷延していた ${ }^{29)}$ 。このメカニズムとして, プラスミン依存的な ERK1/2 パスウェイが活性化さ れず骨芽細胞の増殖が抑制されさらに, tPA は HIF $1 \alpha$ と VEGFA の活性を高め, 新生血管を増加させると いうことも示された.さらに, PAI-1 欠損マウスに おいては, 大きなフェノタイプはなく, 仮骨の増大 とその後速やかな減少が認められるのみであった ${ }^{30)}$.

\section{4. 筋修復と凝固線溶系}

\section{1）筋修復の過程}

人体の筋肉, なかでも骨格筋は関節など骨格を可 動させる重要な筋肉である. 骨格筋組織は筋線維と いう多核な巨大細胞から構成される. 筋線維の細胞 膜と基底膜の間には単核の筋衛星細胞と呼ばれる幹 細胞が存在している.この衛星細胞によって骨格筋 組織が再生する，骨のようにリモデリングを恒常的 に行っているわけではないが, 一旦筋組織が損傷す ると筋衛星細胞が活性化され, 筋芽細胞を経て, 筋 細胞へと分化する。そして複数の筋細胞が融合し, 多核の筋管となり, 新たな筋線維が形成され，それ がもとの筋線維と融合することによって骨格筋が再 生される。

骨損傷と同様, 筋肉の損傷後に産生された細胞外 基質の溶解が非常に重要で, 筋衛星細胞が主な役割 を果たす。筋損傷に伴い線維芽細胞や炎症系細胞, マクロファージが損傷組織を䓹食する。壊死組織が 取り除かれたのち再生血管が起こり, 筋衛星細胞が 増殖する。炎症系細胞から分泌されるとされる MMP-2 や MMP-9 といったメタロプロテアーゼが筋 再生に寄与しているといわれており ${ }^{8,31-33)}$, これら MMPs は uPA-プラスミンによるタンパク質分解カス ケードによって活性化されるとされている ${ }^{34)}$.

筋肉疾患の病態として, 先天的疾患である筋ジス
トロフィは, 筋肉の破壊と変性を繰り返す遺伝的難 治疾患であり, 最も頻度の高いデュシェンヌ型筋ジ ストロフィは DMD 遺伝子の変異によるジストロフィ ンの欠損であるとされている. また 後天的疾患と しては, 筋量減少によるサルコペニア, 筋挫傷の修 復遅延や筋肉内異所性骨化がある。異所性骨化は, 本来形成されるべきでない骨化により, 疼痛や可動 域の制限などが起き，日常生活を著しく制限する。 この病態の原因は諸説あるが ${ }^{35-39)}$, いまだ治療薬開 発に至っていない。

\section{2）線溶系と筋肉修復, 異所性骨化}

プラスミンは筋肉修復と再生にも重要なタンパク であることが示されている ${ }^{34)}$. 筋損傷に伴いフィブ リンの沈着が起き, その後線溶系機能により溶解さ れる. プラスミン活性は受傷後 3〜 5日でピークに達 し, フィブリンと壊死組織を除去し, 新たな筋組織 を再生する。これは M2マクロファージを通して行 われることが分かっている ${ }^{40)}$. 沈着したフィブリン などのデブリスが取り除かれることにより，プラス ミンが VEGF-A や pro-MMP などといった成長因子, 潜在系酵素を活性化し, 筋細胞や新生血管を促進す る. 十分な血行と急性炎症により筋再生が行われる 環境が整い, 筋管が形成され，筋修復が完成する。 デュシェンヌ型筋ジストロフィの動物モデルである ジストロフィン発現を欠損した，DMDマウスは， サルコペニアモデル, 筋肉損傷モデルとして, 広く 筋肉疾患解明に使用されている ${ }^{41)}$. 過去の報告では DMD マウスにおいて MMP-2 がVEGFによる血管再 生に必要だとする報告 ${ }^{31)}$ や，逆に MMP-9 を阻害す ると筋再生が改善したという報告もある ${ }^{33)}$.

そこで, 筋再生促進にDMD マウスの筋損傷にお けるプラスミンの意義を調べるべく, プラスミノゲ ン遺伝子久損マウスと DMD マウスから, $\mathrm{Plg}+/-\mathrm{x}$ DMD マウスを作製したところ，驚くべきことに， 骨格筋内に石灰化が自然発生した ${ }^{42}$ （図 3)。一方, Plg+/-やDMD マウスに抏いて, 自然発生は起こら なかった。これらの結果から, 筋損傷マウスにおけ る筋修復にプラスミンが関与していることが示唆さ れた. 細胞外基質分解酵素が ${ }^{31)}$ プラスミンの作用低 下により産生が低下し, 損傷部位の筋修復が損なわ れ，結果として石灰化を生じたことが示唆された。 


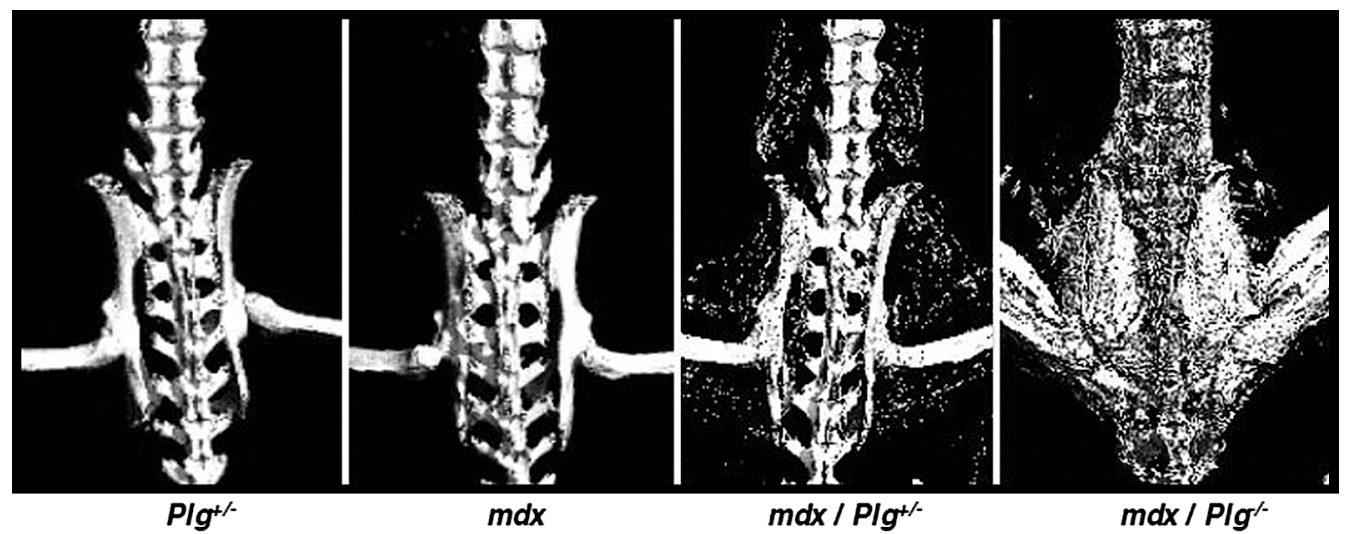

図 3 プラスミノゲンヘテロマウスならびに DMD マウス（mdx）においては石灰化は自然発生しないものの，mdx/Plg+/ならびに mdx/Plg-/ににおて筋肉の存在する骨盤周辺に著明な石灰化を認めた.

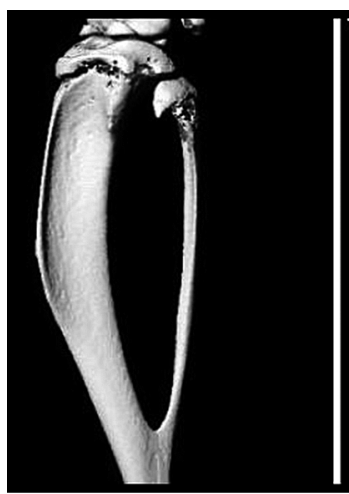

WT

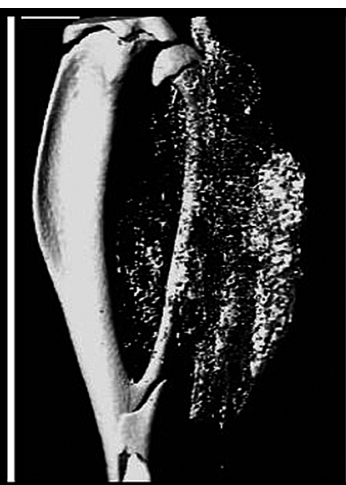

$\mathrm{Plg}^{+/-}$

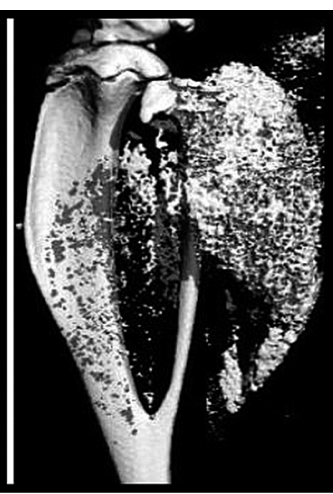

$\boldsymbol{P l g}^{\prime-}$

図 4 筋損傷モデルにおいて，プラスミノゲンヘテロマウスならびにプラスミノゲン欠損マウスで，損傷後筋内に石灰化 （骨化）を形成することが示された.

次にプラスミノゲン遺伝子欠損マウスを用いた下 腿筋損傷モデルにて検証したところ，プラスミノゲ ンヘテロマウスとプラスミノゲン欠損マウスにおい て損傷部位の筋肉組織の治癒不良ならびに石灰化を みとめ, 一部は成熟骨すなわち異所性骨化が形成さ れた（図 4). 病理組織学的に検証すると, プラスミ ンの欠損により, マクロファージの遊走の低下やフィ ブリンの蓄積による慢性的な炎症がもたらされるこ とが示された。この病態にプラスミン活性が重要で あり, 約 50\%のプラスミン活性の低下によって, 石 灰化をもたらし，異所性骨化を形成するということ がわかった。 そこでこのマウスに対し, 薬理学的に $\alpha 2$ プラスミンインヒビターを阻害すると, 損傷部の 治癒の改善と石灰化を防止できた。ささらに, このモ
デルを用いてフィブリン依存性のプラスミンの役割 を検証したところ, この異常石灰化は改善しないこ とが示された。これら結果から，臨床上において， 筋損傷後の正常な筋肉修復と骨化防止に，フィブリ ン非依存性のプラスミン活性が非常に重要な役割を 果たしていることが示唆された.

\section{5. おわりに}

線溶系タンパクであるプラスミンの活性は多様な 筋骨格系の疾患に大きくに関与していることが示さ れている.この筋骨格系疾患の今後の展望としては, フィブリン, プラスミンを中心に凝固/線溶システム を修飾し, 疾患の治療に結び付けることが肝要であ 
る. 特に筋骨格系疾患に関してのマクロファージの 関与は重要であり, それに働きかけるプラスミン活 性のシステムの構築が重要と考えられる。凝固線溶 系を修飾することは出血や血栓のリスクも伴う挑戦 でもあるが, 筋骨格系疾患に対して新たな治療法を 模索したい.

著者全員の利益相反（COI）の開示： 本論文発表内容に関連して開示すべき企業等との利 益相反なし

\section{文献}

1) Sundararaghavan V, Mazur MM, Evans B, Liu J, Ebraheim NA: Diabetes and bone health: Latest evidence and clinical implications. Ther Adv Musculoskelet Dis 9: 67-74, 2017.

2) Baker CE, Moore-Lotridge SN, Hysong AA, Posey SL, Robinette JP, Blum DM, Benvenuti MA, Cole HA, Egawa S, Okawa A, Saito M, McCarthy JR, Nyman JS, Yuasa M, Schoenecker JG: Bone fracture acute phase response-A unifying theory of fracture repair: Clinical and scientific implications. Clin Rev Bone Miner Metab 16: 142-158, 2018.

3) Einhorn TA: Enhancement of fracture-healing. J Bone Joint Surg Am 77: 940-956, 1995.

4) Stocum DL: Regenerative biology and medicine. J Musculoskelet Neuronal Interact 2: 270-273, 2002.

5) Daci E, Everts V, Torrekens S, Van Herck E, TigchelaarGutterr W, Bouillon R, Carmeliet G: Increased bone formation in mice lacking plasminogen activators. J Bone Miner Res 18: 1167-1176, 2003.

6) Daci E, Udagawa N, Martin TJ, Bouillon R, Carmeliet G: The role of the plasminogen system in bone resorption in vitro. $\mathrm{J}$ Bone Miner Res 14: 946-952, 1999.

7) Enderson BL, Chen JP, Robinson R, Maull KI: Fibrinolysis in multisystem trauma patients. J Trauma 31: 1240-1246, 1991.

8) Pepper MS: Role of the matrix metalloproteinase and plasminogen activator-plasmin systems in angiogenesis. Arterioscler Thromb Vasc Biol 21: 1104-1117, 2001.

9) Romer J, Bugge TH, Pyke C, Lund LR, Flick MJ, Degen JL, Dano K: Impaired wound healing in mice with a disrupted plasminogen gene. Nature Med 2: 287-292, 1996.

10) Yuasa M, Mignemi NA, Nyman JS, Duvall CL, Schwartz HS, Okawa A, Yoshii T, Bhattacharjee G, Zhao C, Bible JE, Obremskey WT, Flick MJ, Degen JL, Barnett JV, Cates JMM, Schoenecker JG: Fibrinolysis is essential for fracture repair and prevention of heterotopic ossification. J Clin Invest $\mathbf{1 2 5}$ : 3117-3131, 2015.

11) Carmo AA, Costa BR, Vago JP, de Oliveira LC, Tavares LP, Nogueira CR, Ribeiro ALC, Garcia CC, Barbosa AS, Brasil BSAF, Dusse LM, Barcelos LS, Bonjardim CA, Teixeira MM, Sousa LP: Plasmin induces in vivo monocyte recruitment through protease-activated receptor-1-, MEK/ERK-, and CCR2-mediated signaling. J Immunol 193: 3654-3663, 2014.

12) Roth D, Piekarek M, Paulsson M, Christ H, Bloch W, Krieg T, Davidson JM, Eming SA: Plasmin modulates vascular endothelial growth factor-A-mediated angiogenesis during wound repair. Am J Pathol 168: 670-684, 2006.

13) Shen Y, Guo Y, Mikus P, Sulniute R, Wilczynska M, Ny T, Li $\mathrm{J}$ : Plasminogen is a key proinflammatory regulator that accelerates the healing of acute and diabetic wounds. Blood 119: 5879-5887, 2012.

14) Ploplis VA, French EL, Carmeliet P, Collen D, Plow EF: Plasminogen deficiency differentially affects recruitment of inflammatory cell populations in mice. Blood 91: 2005-2009, 1998.

15) Mahmood N, Mihalcioiu C, Rabbani SA: Multifaceted role of the urokinase-type plasminogen activator (uPA) and its receptor (UPAR): Diagnostic, prognostic, and therapeutic applications. Front Oncol 8: 24, 2018.

16) Yuasa M, Mignemi NA, Barnett JV, Cates JM, Nyman JS, Okawa A, Yoshii T, Schwartz HS, Stutz CM, Schoenecker JG: The temporal and spatial development of vascularity in a healing displaced fracture. Bone 67: 208-221, 2014.

17) Gerstenfeld LC, Cullinane DM, Barnes GL, Graves DT, Einhorn TA: Fracture healing as a post-natal developmental process: Molecular, spatial, and temporal aspects of its regulation. J Cell Biochem 88: 873-884, 2003.

18) Rhinelander FW: Tibial blood supply in relation to fracture healing. Clin Orthop Relat Res 1974: 34-81, 1974.

19) Rhinelander FW, Baragry R: Microangiography in bone healing. I. Undisplaced closed fractures. The J Bone Joint Surg Am 44-a: 1273-1298, 1962.

20) Trueta J: Appraisal of the vascular factor in the healing of fractures of the femoral neck. The Journal of bone and joint surgery British volume 39-b: 3-5, 1957.

21) Rockwood CA GD, Bucholz RW: Rockwood and Green's Fractures In Adults 2010; Philadelphia, Pennsylvania, USA: Wolters Kluwer Health/Lippincott Williams \& Wilkins.

22) Flick MJ, Du X, Witte DP, Jirousková M, Soloviev DA, Busuttil SJ, Plow EF, Degen JL: Leukocyte engagement of fibrin(ogen) via the integrin receptor alphaMbeta2/Mac-1 is critical for host inflammatory response in vivo. J Clin Invest 113: 1596-1606, 2004.

23) Flick MJ, LaJeunesse CM, Talmage KE, Witte DP, Palumbo JS, Pinkerton MD, Thornton S, Degen JL: Fibrin(ogen) exacerbates inflammatory joint disease through a mechanism linked to the integrin alphaMbeta2 binding motif. J Clin Invest 117: 3224-3235, 2007.

24) Cole HA, Ohba T, Nyman JS, Hirotaka H, Cates JM, Flick MJ, Degen JL, Schoenecker JG: Fibrin accumulation secondary to loss of plasmin-mediated fibrinolysis drives inflammatory osteoporosis in mice. Arthritis Rheumatol 66: 2222-2233, 2014.

25) Flick MJ, Du X, Witte DP, Jirouskova M, Soloviev DA, Busuttil SJ, Plow EF, Degen JL: Leukocyte engagement of fibrin(ogen) via the integrin receptor alphaMbeta2/Mac-1 is critical for host inflammatory response in vivo. J Clin Invest 113: 1596-1606, 2004.

26) Lijnen HR: Plasmin and matrix metalloproteinases in vascular remodeling. Thrombosis and haemostasis 86: 324-333, 2001.

27) Kawao N, Tamura Y, Okumoto K, Yano M, Okada K, Matsuo $\mathrm{O}$, Kaji H: Plasminogen plays a crucial role in bone repair. $\mathrm{J}$ Bone Miner Res 28: 1561-1574, 2013.

28) Popa NL, Wergedal JE, Lau KH, Mohan S, Rundle CH: 
Urokinase plasminogen activator gene deficiency inhibits fracture cartilage remodeling. J Bone Miner Metab 32: 124135, 2014.

29) Kawao N, Tamura Y, Okumoto K, Yano M, Okada K, Matsuo $\mathrm{O}$, Kaji H: Tissue-type plasminogen activator deficiency delays bone repair: Roles of osteoblastic proliferation and vascular endothelial growth factor. Am J Physiol Endocrinol Metab 307: E278-288, 2014.

30) Rundle $\mathrm{CH}$, Wang $\mathrm{X}$, Wergedal JE, Mohan S, Lau KH: Fracture healing in mice deficient in plasminogen activator inhibitor-1. Calcif Tissue Int 83: 276-284, 2008.

31) Miyazaki D, Nakamura A, Fukushima K, Yoshida K, Takeda S, Ikeda S: Matrix metalloproteinase-2 ablation in dystrophindeficient $\mathrm{mdx}$ muscles reduces angiogenesis resulting in impaired growth of regenerated muscle fibers. Hum Mol Genet 20: 1787-1799, 2011.

32) Dahiya S, Bhatnagar S, Hindi SM, Jiang C, Paul PK, Kuang S, Kumar A: Elevated levels of active matrix metalloproteinase-9 cause hypertrophy in skeletal muscle of normal and dystrophin-deficient mdx mice. Hum Mol Genet 20: 4345-4359, 2011.

33) Li H, Mittal A, Makonchuk DY, Bhatnagar S, Kumar A: Matrix metalloproteinase-9 inhibition ameliorates pathogenesis and improves skeletal muscle regeneration in muscular dystrophy. Hum Mol Genet 18: 2584-2598, 2009.

34) Suelves M, Lopez-Alemany R, Lluis F, Aniorte G, Serrano E, Parra M, Carmeliet P, Muñoz-Cánoves P: Plasmin activity is required for myogenesis in vitro and skeletal muscle regeneration in vivo. Blood 99: 2835-2844, 2002.

35) Agarwal S, Loder S, Brownley C, Cholok D, Mangiavini L, Li J, Breuler C, Sung HH, Li S, Ranganathan K, Peterson J, Tompkins R, Herndon D, Xiao W, Jumlongras D, Olsen BR, Davis TA, Mishina Y, Schipani E, Levi B: Inhibition of Hif1 $\alpha$ prevents both trauma-induced and genetic heterotopic ossification. Proc Natl Acad Sci U S A 113: E338-347, 2016.

36) Forsberg JA, Pepek JM, Wagner S, Wilson K, Flint J, Andersen RC, Tadaki D, Gage FA, Stojadinovic A, Elster EA: Heterotopic ossification in high-energy wartime extremity injuries: Prevalence and risk factors. J Bone Joint Surg Am 91: 1084-1091, 2009.

37) Kaplan FS, Le Merrer M, Glaser DL, Pignolo RJ, Goldsby RE, Kitterman JA, Groppe J, Shore EM: Fibrodysplasia ossificans progressiva. Best Pract Res Clin Rheumatol 22: 191-205, 2008.

38) Nelson ER, Wong VW, Krebsbach PH, Wang SC, Levi B: Heterotopic ossification following burn injury: The role of stem cells. J Burn Care Res 33: 463-470, 2012.

39) Wozney JM, Rosen V, Celeste AJ, Mitsock LM, Whitters MJ, Kriz RW, Hewick RM, Wang EA: Novel regulators of bone formation: Molecular clones and activities. Science 242: 1528-1534, 1988.

40) Motley MP, Madsen DH, Jürgensen HJ, Spencer DE, Szabo R, Holmbeck K, Flick MJ, Lawrence DA, Castellino FJ, Weigert R, Bugge TH: A CCR2 macrophage endocytic pathway mediates extravascular fibrin clearance in vivo. Blood 127: 1085-1096, 2016.

41) Lu-Nguyen N, Ferry A, Schnell FJ, Hanson GJ, Popplewell L, Dickson G, Malerba A: Functional muscle recovery following dystrophin and myostatin exon splice modulation in aged $\mathrm{mdx}$ mice. Hum Mol Genet 28: 3091-3100, 2019.

42) Mignemi NA, Yuasa M, Baker CE, Moore SN, Ihejirika RC, Oelsner WK, Wallace CS, Yoshii T, Okawa A, Revenko AS, MacLeod AR, Bhattacharjee G, Barnett JV, Schwartz HS, Degen JL, Flick MJ, Cates JM, Schoenecker JG: Plasmin prevents dystrophic calcification after muscle injury. J Bone Miner Res 32: 294-308, 2017. 